\title{
Serbski kulturny leksikon - nowa pomocka w slawistiskim slědźenju
}

\author{
Franc Šěn (Budyšin)
}

\begin{abstract}
Abstrakt
Wěcne leksika a encyklopedije słuža spěšnej informaciji wo datach a mjenach, faktach a ličbach. Za serbsku kulturu a stawizny falowaše dotal tajka pomocka. Nowy němskorěčny Serbski kulturny leksikon (2014) je alfabetisce rjadowana kniha, kotraž w 230 hesłach aktualny staw wědy k žiwjenju Łužiskich Serbow prěni raz systematisce předstaja. Přinošk pokazuje wjac hač 150 lětne prócowanje wo tajku přiručku a jeje wužitnosć za slawistiske slědźenje.
\end{abstract}

\section{Klučove słowa}

serbska kultura; Serbski kulturny leksikon

\section{Abstract}

\section{The Sorbian Lexicon - a New Handbook for Slavonic Research}

The Sorbian Lexicon, a new handbook on Slavonic research is to be used as information source of names, facts and numbers. As there has not been any handbook of Sorbian culture and history so far, the new „Sorbisches Kulturlexikon“ which its more than 230 entries, covers the up-to-date knowledge of modern Sorbian life. This paper then describes the 150-years sustained efforts needed to compile a publication like this.

\section{Key words}

Sorbian culture; the Sorbian Lexicon 
Encyklopedije a wěcne leksika słuža spěšnej informaciji wo datach a mjenach, faktach a wuwićach. Tež slawisća tajke trjebaja, chcedźa-li na př. so wo zjawach we wobłuku sorabistiki chětře wobhonić.

W Němskej dožiwjamy, zo tež w akademiskim wobłuku z wědu wo Serbach, serbskej rěči, literaturje a stawiznach často klaca. Na jednej stronje jedna so wo rěčnokulturne njejasnosće - prašenja spisowneju rěčow, konfesionelna přisłušnosć Serbow a rozdźěl mjez zapřijećomaj Sorben a Wenden. Na druhej stronje jewja stare a nowe politiske předsudki - zo je serbski zakoń kumštny wutwor NDR-skeje mjeńšinoweje politiki, zo w gmejnach z dwurěčnymi taflemi dawno žanych Serbow wjac njeje atd. A to, hačrunjež předleži kopa primarneje a sekundarneje literatury k serbskej rěči, literaturje, ludowědźe a stawiznam, kmanej za kulturnowědomostny diskurs. Špak bě, zo falowaše dotal fachowa synteza, kiž by mjenje abo lěpje přistupne wědomostne wuslědki na wysokim niwowje zjednoćiła a slědźerske běłe blaki zdobom trochu wurunała. Tohodla wobzamknychmy před lětdźesatkom, zdźěłać tajki spis a jón zajimowanej zjawnosći kaž tež wědomosći w formje moderneje encyklopediskeje přiručki poskićić. Před wjac hač lětom je w němskej rěči wušoł 580 stronski słownik Sorbisches Kulturlexikon. ${ }^{1}$

Pytaš-li za nim w interneće, namakaš knihu hišće w poskitku nakładnistwa a knihikupstwow; tež někotre recensiske wothłosy wo njej. W přehledźe pomockow w slawistiskich portalach so dotal lědma jewi. We Wikipediji nańdźech ju jeničce pola němskeho hesła Sorben. Bě tuž cyłe dźěło po prózdnym?

Wotmołwu na to spytam z krótkim stawizniskim zarysom prócowanja wo tajku pomocku, z krótkim předstajenjom našeho kompendija namakać.

Njeje připad, zo nastachu prěnje a za dołhi čas płaćiwe dźéła tajkeho razu we 1840tych lětach, w dobje narodneho wozrodźenja we Łužicy. 1841 a 1843 wuda hišće we Wrócławju studowacy Jan Arnošt Smoler zhromadnje ze sekretarom Łužiskeje towaršnosće wědomosćow dwuzwjazkowu zběrku Volkslieder der Wenden in der Ober- und Nieder-Lausitz = Pjesnički hornych a delnych Eužiskich Serbow. W přidawku k druhemu zwjazkej podawa Smoler přehlad wo serbskich dialektach, rěčnej přestrjeni, wašnjach, nałožkach, hudźbje, twarstwje a serbskej mytologiji. Michał Hórnik mjenuje w Riegerovym slovniku pojednanje "nejlepši posud obšírnějši dilo o lužických Srbech"2 a skoro sto lět pozdźišo rěči Pawoł Nedo wo uniwersalnej ludowědnej encyklopediji.

Jan Arnošt Smoler skutkowaše po studiju jako nowinar a nakładnik za rozwiće serbskeho kulturneho žiwjenja w Budyšinje a słuša k iniciatoram załoženja wědomostneho towarstwa Maćica Serbska w lěće 1847. Kajke wočakowanja na towarstwo staješe wuzna 1858 w lisće slawistej Osipej Maksimowičej Bodjanskemu: „Mój lubušk, moje lube dźéćatko, je naša Maćica Serbska. Jeje organizaciju sym ja w tychle lětach dale wudokonjat, přetož ja sym na to dźětat, zo je so 1) rěčespytna, 2) starožitnostna a historiska, 3) přirodopisna a zemjepisna a 4) beletristiska sekcija zatožiła. Z pomocu tutych sekcijow chcu wudobyć, zo so ludźo $k$ temu priprawja, zo by so po času mata serbska, wšitke wědomosće woprijaca encyklopedija

1 Sorbisches Kulturlexikon. Hrsg. von Franz Schön und Dietrich Scholze unter Mitarbeit von Susanne Hose, Maria Mirtschin und Anja Pohontsch. Bautzen: Domowina-Verlag, 2014. 579 s.

2 RIEGER, František L.: Slovnik naučný. Díl osmý. Praha: Kober, 1870, s. 923. 
wudać móhta. “3 $\mathrm{K}$ tomu drje njedóńdźe, ale bio-, bibliografiske přehlady Korle Awgusta Jenča a 1848 wušły přehlad Jakuba a Kućanka Serbske horne Eužicy aby statistiski zapisk wšitkich serbskich evangelskich a katholskich wosadow běchu hižo dobre stawizniske přinoški w tutym směrje.

Serbow w hesłach sobu zapřijeć chcyše T. G. Masaryk we wot njeho přihotowanej Českej encyklopediji, na kotrež wobdźělištaj so Michał Hórnik, kiž naćisny lisćinu sorabistiskich hesłow, a Adolf Černý. ${ }^{4}$ Projekt njeporadźi so zwoprawdźić, ale Černý sta so za to sobuawtor noweho 28 zwjazkoweho Ottoweho Slovníka naučneho. Serbski publicist Mikławš Andricki měješe na mysli jeho hesła zeserbšćić a wudać jako Łužisku domiznowědu. Černý sam wuži je 1911 za samostatnu knižku Lužice a Lužičtí Srbové, dopjelnjenu z fotami, kiž w stilu wšowědneje encyklopedije wopisuje serbski kraj na kóncu 19. lětstotka a podawa fakty a wuwića ze serbskich stawiznow a kultury.

Dalši namjet zdźělanja zjeća sorabistiskeje wědy pochadźa wot Josefa Páty. We wozjewjenju swojeho přinoška na druhim slawistiskim kongresu 1934 připomina wón: „Přednáška vyvolala živý rozhovor, kterého se zúčastnili vedle československých slavistů zejména slavisté polští. $Z$ rozhovoru vyšel rezolučni návrh na vydáni přiručni vědecké encyklopedie lužickosrbské, předložený H. Batowským, Jos. Pátou a W. Taszyckým na závěrečném slavnostním zasedáni v Krakově dne 29. zárí 1934 a př́tomnými jednomyslně schválený. " ${ }^{5} \mathrm{Na}$ planowanym třizwjazkowym projekće su Páta a dalši slawisća dźěłać započeli, ${ }^{6}$ ale politiske wuwiće w Europje w pózdnich 30tych lětach zadźłła zwoprawdźenju tutoho ambiciozneho předewzaća. Josef Páta sta so 1942 z woporom Heidrichiady.

Potrjebu informaciskich přiručkow začuwachu tež serbscy slědźerjo. Tak wěnowaše so gymnazialny wučer Ota Wićaz lěta dołho rukopisnej bio- a bibliografiskej encyklopediji. Jako so po druhej swětowej wójnje 1946 prěnja serbska institucija - Serbski wučerski wustaw - załoži, namjetowaše Pawoł Nedo inoficialnje skutkowacej Maćicy Serbskej, zdźéłać pod Wićazowym nawodom pjećzwjazkowu serbsku encyklopediju. Skupinka Maćicarjow na tym dźěłaše, ale z politisce wunuzowanym rozpušćenjom towarstwa 1949 so to skónči. W lońšim Lětopisu našeho instituta wozjewjena dokumentacija zachowanych předdźł̌łow k pismikomaj A a B zmóžnja dohlad do koncepcije a charaktera projekta. $^{7}$

Hač do toho časa bě sorabistiske slědźenje we Łužicy amaterske abo połamaterske. Wukonjachu je zwjetša fararjo abo wučerjo pódla swojeho powołanskeho dźěła. To změni so hakle 1951, jako so Serbam poradźi załoženje wědomostneju slědźenišćow a z tym profesionalizacija sorabistiki. W Budyšinje nasta Institut za serbski ludospyt, 1952 přirjadowany Němskeje akademiji wědomosćow, 1992 přeměnjeny na Serbski institut.

3 CYŽ, Jan: Z ruskeho listowanja Jan Arnošta Smolerja. Lětopis A 20, 1973, č. 1, s.112.

4 Přir. KALETA, Petr: Češi o Lužických Srbech. Český vědecký, publicistický a umèlecký zájem o Lužické Srby v 19. století a sorabistické dilo Adolfa Černého. Praha: Masarykův ústav - Archiv AV ČR, 2006, s. 163-168.

5 PÁTA, Josef: O lužickosrbské literární historii a kritice. Slavia 14, 1935-1936, č. 1-2, s. 149.

6 ČERNÝ, Marcel: Sorabica v časopise Slavia a studium sorabistiky na pridě Slovanského ústavu do vzniku Československé akademie věd. In: Sorabistika - metodologie, zkušenosti a budoucí směřování. Eds. Ivo Pospísil - Josef Šaur. Brno: Masarykova univerzita, 2011, s. 63-86.

7 ŠĚN, Franc: Projekt Maćičneje encyklopedije. Lětopis 61, 2014, č. 2, s. 87-115. 
W Lipsku při uniwersiće wutwori so 1951 kubłansko-slědźerski >Institut za sorabistiku<, kiž hač do dźensnišeho wučerjow a dorost za serbske kulturne institucije wukubłuje.

1960 pytachu Budyscy wědomostnicy prěni raz wuši kontakt z mjezynarodnej slawistiku, zarjadujo prěnju Sorabistisku konferencu. Wšelacy přednošowarjo prašachu so na njej za dalšimi nadawkami sorabistiki. Praski rěčespytnik Jan Petr rěčeše bjezposrědnje $O$ potřeb̌ lužickosrbského biografického slowniku. ${ }^{8}$

Traješe pak někotre lěta, doniž so serbske nakładnistwo ze skupinku wědomostnikow a amaterow njezwaži na prěni Serbski biografiski słownik. W lěće 1970 wušła kniha so njedźiwajo brachow prěnjeho pospyta chětře rozpředa. Wosom lět pozdźišo prošeše nakładnistwo wědomostnikow instituta wo wobdźěłany a rozšěrjeny nakład. Wón wuńdźe 1984 jako Nowy biografiski stownik $k$ stawiznam a kulturje Serbow z 800 biografijemi. W nim namakamy tež mjena někotrych Njeserbow, kiž su w serbskich stawiznach rólu hrali.

Za kubłanske zaměry a k powšitkownej informaciji němskeje zjawnosće a wopytowarjow Łužicy nastachu za čas NDR tež skromne edicije z wěcnymi informacijemi, kaž 1989 wušła knižka Sorben - Serbja. Ein kleines Lexikon.

Kedźby hódnišej stej tu słowjanskej literarnowědnej přiručce. 1987 wuda Praske nakładnistwo Odeon w swojim rjedźe słownikow k wukrajnym literaturam Slovnik spisovatelů německého jazyka a spisovateli̊ lužickosrbských, w kotrymž so konsekwentnje serbska literatura jako integralny dźěl do němskeje zarjaduje. Polonist Josef Vlášek spisa 48 medaljonow serbskich awtorow, krótki wuwićowy zarys a časowu tabulku k serbskej literaturje. Nawopak w „przewodniku encyklopedycznym“, kiž wuda 1994 Halina Janaszek-Ivaničková, hdźež liči so serbska runohódnje k zapadosłowjanskim literaturam. ${ }^{9}$ Samostatny, 100-stronski wotstawk z wjac hač 80 hesłami, k połojcy biografiskimi a k połojcy wěcnymi, skutkuje kaž zarodk jedneje serbskeje literarneje encyklopedije.

40 lět po prěnjej konferency zarjadowa 2001 Budyski institut składnostnje swojich 50ćin dalšu mjezynarodnje derje wopytanu sorabistisku konferencu. Tež na njej bě blok přednoškow, kiž zaběrachu so z móžnymi přichodnymi předewzaćemi sorabistiki. Rafał Leszczyński wuwi runjewon konkretny plan „Zadania sorabistyki na pierwsze dziesięciolecie XXI wieku“: Namjetowaše w slědowacych lětach do 2010 wudać tři zwjazkowu encyklopediju w serbskimaj rěčomaj, kiž móhła so pozdźišo tež do němčiny a jendźelšćiny přełožić. ${ }^{10}$

Sam mějach přednošk k podobnej temje: „Sorabistika a jeje přiručki“. Rozestajach so kritisce z dotalnym poskitkom a z tym, što je nam w nětčišej situaciji trjeba. Pleděrowach za jedno-zwjazkowy němskorěčny sorabistiski leksikon, kiž měł wotwarjeć njewědu mjez Němcami, z kotrymiž wšak smy w najwušim susodstwje žiwi, předstajeć histori-

8 PETR, Jan: O potřebě lužickosrbského biografického slowniku. Lětopis A 8, 1961, s. 62-67.

9 JANASZEK-IVANIČKOVÁ, Halina (ed.): Literatury zachodniostowiańskie czasu przetomów 1890-1990. 1. Literatura tużycka i stowacka; Przewodnik encyklopedyczny. Katowice: Śląsk, 1994.

10 LESZCZYŃSKI, Rafał: Zadania sorabistyki na pierwsze dziesieciolecie XX wieku. In: Im Wettstreit der Werte : sorbische Sprache, Kultur und Identität auf dem Weg ins 21. Jahrhundert. Hrsg. Dietrich Scholze. Bautzen: Domowina-Verlag, 2003, s. 393-398. 
ske kulturne wukony Serbow, budźić mjez nimi zajim to „serbske“ a nadeńdź tak zwjazkarjow we wšědnym boju wo finančnu přiražku za serbske kulturne prócowanja.

Našeho direktora, Dietricha Šołtu, tuta ideja bóle zaja. 2003 započachmy w Serbskim instituće tajki němskorěčny leksikon koncipować a do planow přiwzać. Jeho wuwiće a wobdźěłanje hesłow traješe naposledk njewočakowane 10 lět. Wjetšinu tych 230 hesłow spisachu naši sobudźěłaćerjo, specielne temy wobdźěłachu ca. 60 eksternych specialistow. Ludowe nakładnistwo Domowina přewza wudaće a rozšěrjenje tutoho kompendija.

Z hesłami kaž alfabet, archiwy, biblioteki hač k Zwjazkam wuměłcow zmóžnja leksikon wobšěrny dohlad do pisanosće serbskeje kultury, jeje historiskeho nastaća a rósta.

Nimo ćežišćow - historiske wuměnjenja, materielna kultura, duchowna kultura, wšědna kultura, institucije - posrědkuja regionalne hesła wobraz wšelakorosće lokalneho wuraza. Hornja a Delnja Łužica kaž tež hornjo- a delnjoserbšćina so po móžnosći w jenakej měrje wobkedźbowachu.

Njewotmołwjeja so jenož standardne prašenja kaž za rozdźělom mjez pomjenowanjomaj Sorben a Wenden ale tež: Wot hdy je serbskich nowin, hdźe wšudźe namakamy serbske dróhi, kak nasta mytos wo Krabaće, kak wuwiwaše so serbski prawopis, kak wobchadźa serbšćina z cuzymi słowami, kelko dialektow znaje serbšćina, kak bě a je ze serbskimi šulemi atd.

Historiske hesła njerozprawjeja jenož wo zańdźenych podawkach ale swědča tež wo zhromadnym žiwjenja ludow z typiskimi formami kaž potłóčowanje, ćerpjenje a spěchowanje mjeńšeho přez wjetšeho. Ale tež k zjawam kaž panslawizm abo nastaću swójskeje hymny a druhich symbolow wě leksikon wotmołwy.

Hesła su přezcyłnje tež za prosteho čitarja zrozumliwje napisane, tak zo njeskića jenož fachowcej sorabistiski slědźerski rezimej ale tež lajkej zakładne znajomosće.

Zakónčacy wosobowy a městny register zmóžnitaj wotkywać dalše zwiski.

Kritika je Serbski kulturny leksikon z wjele chwalbu přiwzała. Wo knize lětstotka pisaše nowina Lausitzer Rundschau, wo najwažnišej sakskej knize nalěća 2014 Sächsische Zeitung.

K wuspěchej wjele přinošowała je bjez dwěla zhotowjerka, wuměłča Iris Brankačkowa, kiž zhotowi specielne karty za jednotliwe hesła kaž za demografiske wuwiće abo zničenje sydlenskeho ruma přez wudobywanje wuhla.

Njesnadny podźěl na rjanym wuhotowanju ma tež fotowy archiw Serbskeho kulturneho archiwa, kiž wjetši dźěl tych 700 „přemysliwje wubranych a tohodla wuprajiwych"11 wobrazow přinošowaše.

Z tutej přiručku bu wažny nadawk sorabistiki spjelnjeny a wona stanje so nadźijomnje bórze ze standardnej literaturu. Wšak pisa čěski recensent, historikar Petr Kaleta, w Slovanským přehledźe: „Lužickosrbský kulturni lexikon je zdařilou vědeckou syntézou, která odborniky, ale i laickou veřejnost velmi čtivě a zároveň vyváženě a na patřičné vědecké

11 Recensent Jens Bulisch. Zeitschrift für Slawistik 60, 2015, č. 1, s. 162. 
úrovni informuje o lužickosrbské kultuře a vypovidá o nejnovějšich výsledcích sorabistických disciplín a o činnosti lužickosrbských vědeckých a kulturních institucí. Jde proto o dílo, jež by nemělo chybět v žádném slavisticky zaměreném vědeckém pracovišti nebo knihovně." ${ }^{2}$

Franc Šěn, dr. phil.

Karl-Liebknechtowa 18, D-02625 Budyšin/Bautzen, Německo

f-sen@gmx.de

12 Slovanský přehled 101, 2015, č. 1, s. 181. 